\title{
Potensi Autoalelopati Ekstrak Daun Kirinyuh (Chromolaena odorata L.)
}

\section{The Potential Allelophatic of Leaf Kirinyuh Extract}

\author{
Diah Ziadaturrif'ah ${ }^{1}$, Sri Darmanti ${ }^{2 *}$, Rini Budihastuti ${ }^{2}$ \\ ${ }^{1}$ Mahasiswa Program Studi Biologi, Departemen Biologi, Fakultas Sains dan Matemtika, \\ Universitas Diponegoro \\ ${ }^{2}$ Departemen Biologi, Fakultas Sains dan Matematika, Universitas Diponegoro \\ *Email : darmantisri@yahoo.co.id
}

Diterima 25 Juli 2019 / Disetujui 23 Agustus 2019

\begin{abstract}
ABSTRAK
Kirinyuh (Chromolaena odorata L.) merupakan salah satu gulma yang memiliki senyawa alelokimia yang dapat menghambat pertumbuhan tanaman yang ada disekitarya, baik yang sejenis maupun yang berbeda sejenis. Karena kemapuan yang dimiliki tersebut, diduga kirinyuh berpotensi digunakan sebagai herbisida alami. Penelitian ini bertujuan untuk mengetahui pengaruh ekstrak air daun kirinyuh pada konsentrasi yang berbeda terhadap pertumbuhan gulma yang sama, yaitu kirinyuh dan menentukan konsentrasi ekstrak air daun kirinyuh yang menyebabkan penghambatan pertumbuhan terbesar pada gulma kirinyuh. Penelitian menggunakan Rancangan Acak Lengkap (RAL) faktor tunggal berupa konsentrasi ekstrak air daun kirinyuh yaitu $0 \%, 10 \%, 20 \%, 30 \%$ dan 40\%. Masing-masing perlakuan dengan lima ulangan. Parameter yang diamati adalah pertumbuhan vegetative meliputi : tinggi tanaman, panjang akar, bobot basah akar dan tajuk, bobot kering akar dan tajuk, luas daun, jumlah daun, kandungan klorofil a, klorofil b, klorofil total, karotenoid serta lebar mulut stomata. Data dianalisis dengan Analisys of Variance (ANOVA) dan dilanjutkan Duncan's Multiple Range Test (DMRT) pada taraf kepercayaan 95\%. Hasil penelitian menunjukkan bahwa ekstrak daun kirinyuh bersifat autoalelopati yaitu menghambat semua parameter pertumbuhan vegetatif yang diukur, semakin tinggi kosentrasi ekstrak dari $10 \%$ sampai $40 \%$ penghambatan pertumbuhan semakin kuat.
\end{abstract}

Kata kunci: autoalelokimia, bioherbisida, gulma, kirinyuh, Chromolaena odorata L.

\begin{abstract}
Kirinyuh (Chromolaena odorata L.) is one weed that has allelochemical compounds that can inhibit the growth of plants around it, both similar and different plant type. Because of the ability that is owned, it is thought that the potential for use is a natural herbicide. The aim of this study was to determine the effect of kirinyuh leaf water extract on different concentrations on the same weed growth, which was to improve and determine the concentration of kirinyuh leaf water extract which caused the greatest inhibition of growth in weeds. The study used a Completely Randomized Design (CRD) single factor in the form of kirinyuh leaf extract water concentrations of $0 \%, 10 \%, 20 \%, 30 \%$ and $40 \%$. Each treatment with five replications. The parameters observed were vegetative growth including: plant height, root length, root and shoot fresh weight, root and shoot dry weight, leaf area, leaf number, chlorophyll a, chlorophyll $\mathrm{b}$, total chlorophyll, carotenoid content and stomata hole width. Data were analyzed by Analysis of Variance (ANOVA) and continued the Duncan's Multiple Range Test (DMRT) at the 95\% confidence level. The results showed that kirinyuh leaf extract was autoalelopathic, which inhibited all parameters of measured vegetative growth, the higher the concentration of extract from $10 \%$ to $40 \%$ the stronger the growth inhibition.
\end{abstract}

Keywords: autoalelochemistry, bioherbicide, weeds, kirinyuh, Chromolaena odorata L.

\section{PENDAHULUAN}

Gulma merupakan tanaman yang tumbuh ditempat yang tidak diinginkan. Kehadiran gulma dapat mengganggu pertumbuhan tanaman yang ada disekitarnya (Sindel dan Coleman, 2010). Kirinyuh (Chromolaena odorata L.) adalah salah satu gulma padang rumput yang sangat 
merugikan karena dapat mengurangi daya tampung padang penggembalaan dan juga dapat menyebabkan keracunan bahkan kematian pada hewan ternak. Gulma tersebut sering dijumpai dilahan yang kosong dengan pertumbuhan yang lebat dan menggerombol. Gulma kirinyuh diduga memiliki pertahanan yang cukup tinggi karena sangat mudah tumbuh meskipun sudah ditebangi (Thamrin dkk, 2013).

Pengendalian gulma yang ramah lingkungan merupakan salah satu alternatif yang dapat dilakukan yaitu dengan memanfaatkan potensi senyawa kimia yang berasal dari tumbuhan yang bersifat alelopati sehingga dapat dimanfaatkan sebagai bioherbisida. Salah satu tumbuhan yang diduga memiliki potensi digunakan sebagai bioherbisida dengan prinsip alelokimia adalah gulma kirinyuh karena mengandung senyawa aktif antara lain senyawa alkaloid, tanin, flavonoid (eupatorin), saponin dan fenolik (Frastika dkk, 2017). Mekanisme penghambatan oleh alelokimia dimulai dari masuknya alelokimia pada bagian membran plasma tanaman target yang menyebabkan hilangnya permeabilitas membran dan hilangnya fungsi enzim ATP-ase. Proses ini akan berpengaruh terhadap penyerapan ion dan air yang kemudian mempengaruhi pembukaan stomata dan proses fotosintesis. Hambatan berikutnya terjadi dalam proses sintesis protein, pigmen dan senyawa karbon lain, serta aktivitas beberapa fitohormon. Sebagian atau seluruh hambatan tersebut kemudian menyebabkan terganggunya pembelahan dan perbesaran sel yang akhirnya menghambat pertumbuhan dan perkembangan tanaman (Sharma et al, 2012; Darmanti, 2018).

Autoalelopati merupakan suatu fenomena interaksi antara individu sejenis dengan perantaraan senyawa alelokimia.. Alelokimia tersebut dapat mematikan atau menghambat anaknya sendiri atau individu lain yang sama sejenisnya (autotoxin) (Junaedi dkk, 2016). Djazuli, 2011 juga menyebutkan bahwa akar gulma mengeluarkan senyawa asam organik yang bersifat toksik pada proses alelopati yang bisa menghambat pertumbuhan gulma itu sendiri atau yang disebut (autotoxin). Pada penelitian ini, dikaji efektivitas ekstrak daun kirinyuh terhadap perkecambahan dan pertumbuhan biji gulma kirinyuh untuk mengetahui potensi autoalelopati gulma kirinyuh sehingga dapat dimanfaatkan sebagai bioherbisida alami untuk memberantas gulma sejenis yaitu kirinyuh.

\section{METODE PENELITIAN}

Bahan utama yang digunakan adalah daun dan biji kirinyuh yang diperoleh di daerah Tembalang, Semarang Jawa Tengah. Alat utama yang digunakan adalah timbangan digital, spektrofotometer UV-Vis, mikroskop dan kamera optilab.

Larutan stok ekstrak daun kirinyuh dibuat dengan konsentrasi 100\%. Ekstraksi kirinyuh menggunakan metode Darmanti et al (2015), yaitu daun kirinyuh dikering anginkan pada kondisi gelap selama 24 jam. Daun dihaluskan dengan menggunakan blender, kemudian diekstraksi dengan air dengan rasio 1:1 (berat/volume) selama 24 jam. Ekstrak disaring 2 kali menggunakan kain dan kertas saring sehingga diperoleh ekstrak konsentrasi $100 \%$. Ekstrak dengan konsentrasi perlakuan $10 \%$, 20\% $30 \%$ dan $40 \%$, dibuat dengan cara mengencerkan stok dengan air. Sebelum digunakan ekstrak disimpan pada suhu rendah. Kontrol dibuat dengan menggunakan air tanpa penambahan ekstrak.

Benih kirinyuh ditanam dengan cara disebar diatas permukaan media tanah dalam polybag, dan disiram setiap hari dengan volume yang sama sampai 14 hari. Tanaman diseleksi berdasarkan tinggi dan jumlah yang sama, sebanyak satu tanaman dalam tiap polybag dan diaklimatisasi selama 7 hari. Perlakuan dilakukan dengan cara disemprot pada seluruh permukaan daun sebanyak $10 \mathrm{ml}$ tiap tanaman, dua hari sekali pada pagi hari sampai 30 hari perlakuan.

Pengamatan pertumbuhan berupa tinggi tanaman, jumlah daun, panjang akar, bobot segar tajuk dan akar, bobot kering tajuk dan akar, luas daun, klorofil a, klorofil b, klorofil total, karotenoid dan lebar celah stomata yang dilakukan pada akhir penelitian.

Pengukuran kadar klorofil dilakukan dengan menggunakan metode Hendry and Grime (1993). Daun kirinyuh sebanyak $0.1 \mathrm{~g}$ dipotong potong 
daun dihancurkan dengan menggunakan mortar dan alu dan ditambahkan $10 \mathrm{ml}$ aseton $80 \%$. Maserasi silakukan beberapa saat sampai klorofil larut, lalu saring dengan kertas saring. Sebanyak 3 ml larutan dimasukkan ke dalam kuvet dan dianalisis dengan menggunakan spektorfotometer dengan panjang gelombang 645 dan 663 dan 480 nm. Konsentrasi klorofil dihitung dengan menggunakan rumus sebagai berikut:

$$
\begin{gathered}
\text { Klorofil a }(\mathrm{mg} / \mathrm{L})=12,7(A 663)-2,69(A 645) \\
\text { Klorofil b }(\mathrm{mg} / \mathrm{L})=22,9 A 645)-4,68(A 645) \\
\text { Klorofil Total }(\mathrm{mg} / \mathrm{L})=8,02 A 663)+20,2(A 645) \\
\text { Karotenoid }=\frac{\left\{\left(\mathrm{A}_{480}+\left(0.114 \times \mathrm{A}_{663}-0.638 \times \mathrm{A}_{645}\right) \times \mathrm{V} \times 10^{3}\right)\right\}}{112,5 \times 0,1 \times 10}
\end{gathered}
$$

Sampel daun kirinyuh yang digunakan adalah daun ketiga dari pucuk tanaman. Permukaan epidermis bawah daun diolesi cat kuku, dibiarkan kering selama 5 -10 menit. Pengukuran lebar celah stomata dilakukan dibawah mikroskop dengan kamera optilab (Haryanti dan Meirina, 2009). Data yang diperoleh pada penelitian ini di analisis menggunakan Uji Anova dengan taraf kepercayaan 95\%. Jika hasil yang diperoleh berbeda nyata maka dilakukan uji lanjut berupa uji Duncan taraf 5\%.

\section{HASIL DAN PEMBAHASAN}

\section{Kandungan Pigmen Fotosintetik}

Hasil uji ANOVA pada taraf kepercayaan 95\% menunjukkan bahwa ekstrak daun kirinyuh berpengaruh nyata terhadap kandungan klorofil a, klorofil $\mathrm{b}$, klorofil total dan karotenoid pada daun tanaman yang sama yaitu kirinyuh (Tabel 1). Perlakuan ekstrak daun kirinyuh menyebabkan terjadinya penurunan pigmen fotosintetik pada gulma kirinyuh. Penurunan kandungan klorofil a, klorofil total dan karotenoid terjadi padaperlakuan konsentrasi ekstrak 30\% yang tidak berbeda nyata dengan perlakuan konsentrasi $40 \%$, sedangkan penurunan pada klorofil $b$ terjadi pada konsentrasi $20 \%$ yang tidak berbeda nyata dengan perlakuan konsentrasi $30 \%$ dan $40 \%$. Penurunan terjadi seiring dengan bertambahnya konsentrasi ekstrak yang diberikan.

Klorofil merupakan molekul kompleks yang berfungsi untuk menyerap cahaya, transfer energi dan elekron dalam proses fotosintesis. Kandungan klorofil daun dapat digunakan sebagai parameter untuk melihat respon tanaman terhadap cekaman lingkungan, termasuk berupa senyawa alelokimia. Hasil penelitian menunjukkan bahwa semua perlakuan alelokimia ekstrak daun kirinyuh menurunkan kandungan klorofil a, klorofil b, klorofil total dan karotenoid gulma kirinyuh jika dibandingkan dengan kontrol yang mengindikasikan bahwa gulma kirinyuh mengalami cekaman. Hal ini sejalan dengan penelitian Susilowati (2012) pemberian alelokimia ekstrak daun kirinyuh mampu mengurangi kadar klorofil dan karotenoid gulma bayam duri. Penurunan kadar pigmen fotosintetik pada gulma kirinyuh tersebut disebabkan oleh senyawa alelokimia yang merusak permeabilitas membran sehingga berdampak pada organel lain yang berada di dalam membrane sel yaitu mitokondria, kloroplas dan vakuola. Terhambatnya aktivitas kloroplas di dalam sel dapat mempengaruhi sintesis klorofil dan karotenoid. Menurut $\mathrm{Yu}$ et al. (2003) efek alelokimia pada fotosintesis dipengaruhi oleh faktor lingkungan seperti intensitas cahaya, suhu, konsentrasi $\mathrm{CO}_{2}$, ketersediaan air, dan mikroorganisme tertentu. Senyawa alelokimia mempengaruhi transportasi electron dalam kloroplas dan mitokondria yang menghambat photosystem II (PS II). Penghambatan mitokondria dan kloroplas rantai transport electron akan menghilangkan sumber energi sel, yaitu NADPH, FAD dan ATP serta dan produk metabolik (Zhou \& Yu 2006; ShannonFirestone \& Firestone 2015), dengan menghilangkan sumber energi sel ini, maka pembentukan klorofil yang terhamba tmengakibatkan proses fotosintesis menurun dan metabolisme primer juga terhambat. 
Karotenoid berfungsi sebagai fitoproteksi yakni menyerap dan membuang cahaya berlebihan yang dapat merusak klorofil atau yang dapat berinteraksi dengan oksigen membentuk molekul oksidatif reaktif yang berbahaya bagi sel, gen yang meregulasi karotenoid berhubungan dengan gen biosintesis klorofil dan keduanya diatur oleh keberadaan cahaya. Sintesis klorofil berhubungan dengan sintesis karotenoid karena proses sintesisnya diregulasi oleh fotoreseptor yang sama yaitu fitokrom (Champbell et al. 2010), sehingga apabila kadar klorofil menurun maka kadar karotenoid juga mengalami penurunan.

Tabel 1. Kandungan pigmen fotosintetik gulma kirinyuh akibat pengaruh ekstrak air gulma kirinyuh selama 30 hari

\begin{tabular}{ccccc}
\hline $\begin{array}{c}\text { Konsentrasi } \\
\text { Ekstrak }\end{array}$ & Klorofil A (mg/l) & $\begin{array}{c}\text { Klorofil B } \\
(\mathrm{mg} / \mathrm{l})\end{array}$ & $\begin{array}{c}\text { Klorofil Total } \\
(\mathrm{mg} / \mathrm{l})\end{array}$ & Karotenoid (mg/l) \\
\hline $0 \%$ & $6.88^{\mathrm{a}}$ & $4.49^{\mathrm{a}}$ & $9.75^{\mathrm{a}}$ & $0.0167^{\mathrm{a}}$ \\
$10 \%$ & $6.81^{\mathrm{a}}$ & $4.46^{\mathrm{a}}$ & $9.66^{\mathrm{a}}$ & $0.0154^{\mathrm{ab}}$ \\
$20 \%$ & $6.44^{\mathrm{a}}$ & $3.75^{\mathrm{b}}$ & $9.21^{\mathrm{a}}$ & $0.0146^{\mathrm{ab}}$ \\
$30 \%$ & $5.53^{\mathrm{b}}$ & $3.73^{\mathrm{b}}$ & $7.66^{\mathrm{b}}$ & $0.0130^{\mathrm{bc}}$ \\
$40 \%$ & $5.02^{\mathrm{b}}$ & $3.63^{\mathrm{b}}$ & $7.23^{\mathrm{b}}$ & $0.0114^{\mathrm{c}}$ \\
\hline
\end{tabular}

Keterangan: Angka yang diikuti dengan huruf yang sama pada kolom yang sama menunjukkan pengaruh yang tidak berbeda nyata berdasarkan uji Duncan dengan taraf kepercayaan $95 \%$.

Tinggi Tanaman, Panjang Akar, Luas Daun, Jumlah Daun dan Lebar Celah stomata

Hasil uji Analysis of Variance (ANOVA) pada taraf signifikansi $95 \%$ menunjukkan bahwa ekstrak daun kirinyuhmemberikan pengaruh nyata terhadap, tinggi tanaman, panjang akar, luas daun, jumlah daundan lebar celah stomata gulma kirinyuh. Pemberian ekstrak kirinyuh mampu menurunkan tinggi tanaman, panjang akar, luas daun dan jumlah daun gulma kirinyuh (Tabel 2).

Penurunan tinggi tanaman dan panjang akar dan jumlah daun mulai terjadi pada konsentrasi $20 \%$, sedangkan luas daun mulai terjadi penurunan pada konsentrasi $10 \%$. Penurunan terjadi seiring dengan bertambahnya konsentrasi ekstrak yang diberikan.

Tabel 2. Tinggi tanaman $(\mathrm{cm})$, Panjang akar $(\mathrm{cm})$ dan luas daun $\left(\mathrm{cm}^{2}\right)$ gulma kirinyuh akibat pengrauh ekstrak air daun gulma kirinyuh selama 30 hari

\begin{tabular}{cccccc}
\hline $\begin{array}{c}\text { Konsentrasi } \\
\text { Ekstrak }\end{array}$ & $\begin{array}{c}\text { Tinggi } \\
\text { Tanaman }(\mathrm{cm})\end{array}$ & $\begin{array}{c}\text { Panjang Akar } \\
(\mathrm{cm})\end{array}$ & $\begin{array}{c}\text { Luas daun } \\
\left(\mathrm{cm}^{2)}\right.\end{array}$ & $\begin{array}{c}\text { Jumlah Daun } \\
(\text { helai })\end{array}$ & $\begin{array}{c}\text { Lebar Celah } \\
\text { Stomata } \\
(\text { um })\end{array}$ \\
\hline $0 \%$ & $4.20^{\mathrm{a}}$ & $15.08^{\mathrm{a}}$ & $49.87^{\mathrm{a}}$ & $7.08^{\mathrm{a}}$ & $3.58^{\mathrm{a}}$ \\
$10 \%$ & $3.78^{\mathrm{a}}$ & $12.86^{\mathrm{a}}$ & $27.15^{\mathrm{b}}$ & $6.68^{\mathrm{ab}}$ & $3.13^{\mathrm{ab}}$ \\
$20 \%$ & $2.92^{\mathrm{b}}$ & $9.70^{\mathrm{b}}$ & $16.38^{\mathrm{bc}}$ & $6.44^{\mathrm{bc}}$ & $2.56^{\mathrm{b}}$ \\
$30 \%$ & $2.54^{\mathrm{bc}}$ & $8.40^{\mathrm{b}}$ & $10.26^{\mathrm{c}}$ & $6.08^{\mathrm{cd}}$ & $2.52^{\mathrm{b}}$ \\
$40 \%$ & $2.30^{\mathrm{c}}$ & $7.22^{\mathrm{b}}$ & $6.61^{\mathrm{c}}$ & $5.68^{\mathrm{d}}$ & $1.71^{\mathrm{c}}$ \\
\hline
\end{tabular}

Keterangan: Angka yang diikuti dengan huruf yang sama pada kolom yang sama menunjukkan pengaruh yang tidak berbeda nyata berdasarkan uji Duncan dengan taraf kepercayaan $95 \%$.

Penghambatan pertumbuhan tinggi tanaman, panjang akar, jumlah daun, dan luas daun disebabkan oleh alelokimia fenol yang masuk melewati membran plasma akan mengikat protein membentuk protein kompleks yang mengakibatkan sel mengalami keracunan dan depolarisasi membran, hal ini akan mengakibatkan terganggunya pengaktifan hormone karena pengaktifan hormone harus dikenali oleh protein, hormone pertumbuhan seperti hormone auksin yang berperan dalam pemanjangan sel dan hormone sitokinin yang berperan dalam 
pembelahan dan pembentangan sel. Adanya alelokimia ekstrak daun kirinyuh menyebabkan terganggunya hormone tersebut sehingga akan berdampak pada penurunan pertumbuhan gulma kirinyuh.

Pertumbuhan merupakan suatu proses pertambahan jumlah, ukuran dan volume sel yang bersifat irreversible. Mekanisme pertumbuhan menurut Song Ai \& Risvi (2010) diawali dengan aktifnya metabolism jaringan pada waktu imbibisi sehingga menyebabkan embrio memproduksi sejumlah kecil giberelin. Hormon tersebut berdifusi ke dalam selapis sel aleurone yang mengelilingi sel dan menjadi bentuk terlarut, pada proses ini sitokinin dan auksin terbentuk yang kemudian merangsang pertumbuhan embrio dan membuat sel-selnya membelah dan membesar. Adanya cekaman berupa alelokimia dapat menyebabkan terganggunya pembelahan dan pembesaran sel sehingga pertumbuhan tinggi tanaman, panjang akar dan luas daun menjad iterhambat. Sesuai dengan hasil penelitian yang dilakukan oleh Anggriani dkk (2013) pemberian ekstrak daun kirinyuh menghambat pertumbuhan gulma rambatan seiring dengan bertambahnya konsentrasi ekstrak yang diberikan.

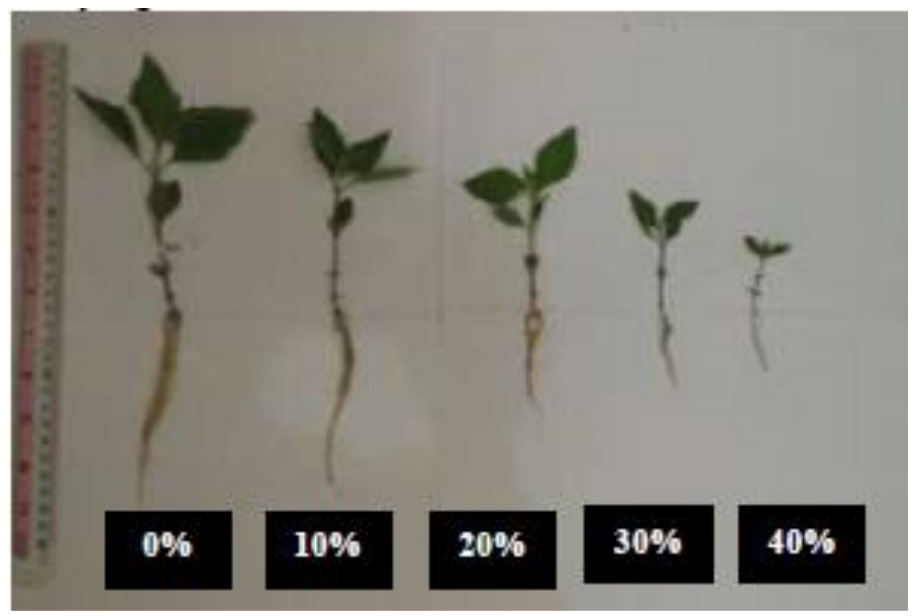

Gambar 1. Gulma kirinyuh akibat perlakuan ekstrak daun kirinyuh pada konsentrasi yang berbeda selama 30 hari

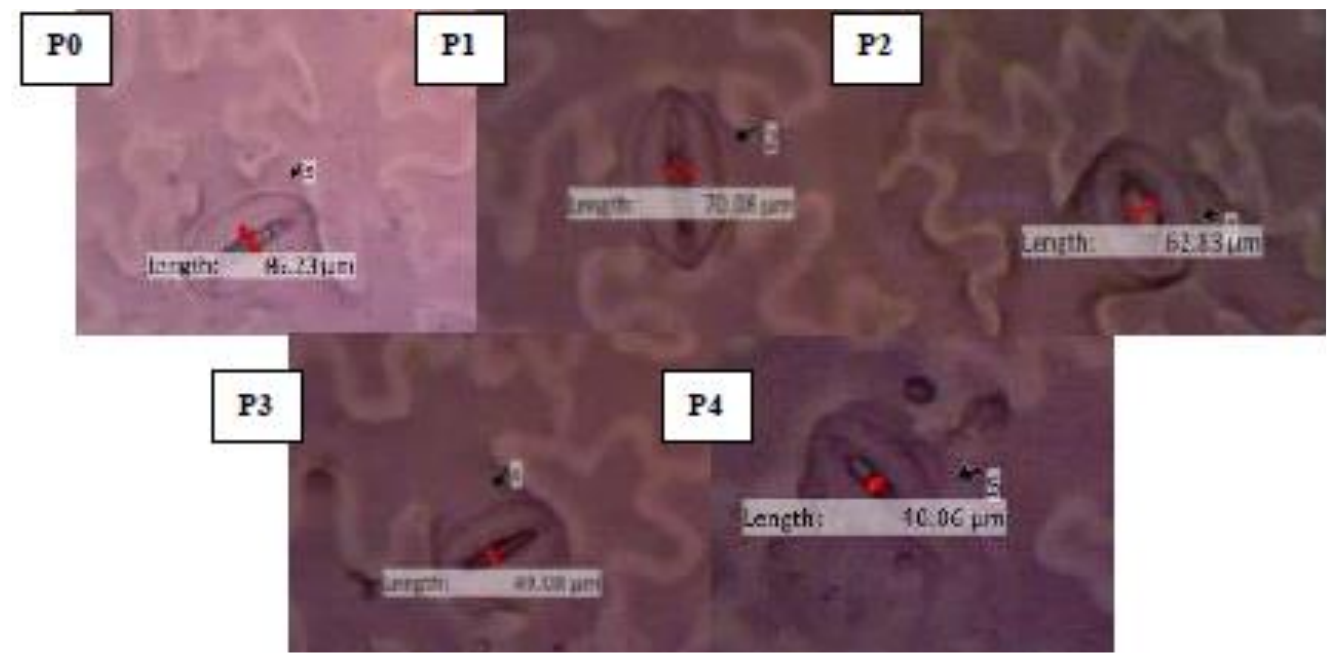

Gambar 2. Lebar lubang stomata daun kirinyuh akibat perlakuan ekstrak daun kirinyuh pada konsentrasi yang berbeda. P0 : 0\%, P1 : 10\%, P2 : 20\%, P3 : 30\% dan P4 : $40 \%$. 
Hasil penelitian menunjukkan bahwa alelokimia ekstrak daun kirinyuh menghambat pembukaan lubang stomata. Penyempitan atau penurunan ukuran lebar celah stomata ini diduga karena alelokimia merusak permeabilitas membran plasma sehingga menyebabkan penyerapan konsentrasi ion $\mathrm{K}$ akan terhambat, yang mana ion $\mathrm{K}$ merupakan ion yang berpengaruh dalam pembukaan dan penutupan stomata. Menurut Li et al. (2010), fungsi stomata dipengaruhi oleh banyak faktor seperti status air, konsentrasi ion $\mathrm{K}$ dan sinyal ABA. Alelokimia mempengaruhi pembukaan stomata secara tidak langsung dengan memodifikasi status air, keseimbangan hormon dan penyerapan ion. Akar adalah organ pertama yang berhubungan langsung dengan alelokimia, akibatnya penyerapan air serta ion akan terganggu dan akumulasi ABA akan meningkatyang kemudian mempengaruhi lebar pembukaan stomata dan proses fotosintesis. Yulifrianti (2015) juga menyatakan bahwa hambatan penyerapan air oleh senyawa fenol menyebabkan kadar air menjadi rendah akibatnya terjadi penurunan pembukaan stomata. Hasil penelitian menunjukkan bahwa masuknya feno lmenghambat pembukaan stomata selanjutnya, konsentrasi ion $\mathrm{K}$ dalam sel penjaga berkurang secara signifikan dan penutupan stomata secara langsung berkaitan dengan kemampuan untuk menghambat masuknya ion $\mathrm{K}$ kedalam sel penjaga.

Tabel 3. Bobot segar (g) dan bobot kering (g) akar dan tajuk gulma kirinyuh akibat pengaruh ekstrak air daun gulma kirinyuh selama 30 hari

\begin{tabular}{|c|c|c|c|c|}
\hline \multirow[b]{2}{*}{$\begin{array}{c}\text { Konsentrasi } \\
\text { ekstrak }\end{array}$} & \multicolumn{2}{|c|}{ Tajuk } & \multicolumn{2}{|c|}{ Akar } \\
\hline & BS (g) & BK (g) & $\mathrm{BS}(\mathrm{g})$ & BK (g) \\
\hline $0 \%$ & $1.19^{\mathrm{a}}$ & $0.198^{\mathrm{a}}$ & $0.568^{\mathrm{a}}$ & $0.0924^{\mathrm{a}}$ \\
\hline $10 \%$ & $0.47^{b}$ & $0.078^{\mathrm{b}}$ & $0.344^{\mathrm{b}}$ & $0.0560^{\mathrm{b}}$ \\
\hline $20 \%$ & $0.44^{\mathrm{b}}$ & $0.074^{\mathrm{b}}$ & $0.136^{\mathrm{c}}$ & $0.0218^{c}$ \\
\hline $30 \%$ & $0.28^{\mathrm{b}}$ & $0.046^{\mathrm{b}}$ & $0.132^{c}$ & $0.0217^{\mathrm{c}}$ \\
\hline $40 \%$ & $0.17^{b}$ & $0.029^{\mathrm{b}}$ & $0.102^{c}$ & $0.0170^{\mathrm{c}}$ \\
\hline
\end{tabular}

Keterangan: Angka yang diikuti dengan huruf yang sama pada kolom yang sama menunjukkan pengaruh yang tidak berbeda nyata berdasarkan uji Duncan dengan taraf kepercayaan 95\%.

\section{Bobot Segar dan Bobot Kering Akar dan Tajuk}

Hasil uji Analysis of Variance (ANOVA) pada taraf signifikansi $95 \%$ menunjukkan bahwa ekstrak daun kirinyuhmemberikan pengaruh nyata terhadap, bobot segar dan bobot kering akar dan tajuk gulma kirinyuh. Pemberian ekstrak kirinyuhmampu menurunkan bobot segar dan bobot kering akar dan tajuk gulma kirinyuh (Tabel 3). Penurunan bobot segar dan bobot kering tajuk secara nyata terjadi pada perlakuan konsentrasi $10 \%$ yang tidak berbeda nyata dengan perlakuan konsentrasi 20\%, 30\% dan 40\%, sedangkan penurunan bobot segar dan bobot kering akar secara nyata terjadi pada perlakuan konsentrasi $10 \%$ dan $20 \%$, namun perlakuan konsentrasi $20 \%$ tidak berbeda nyata dengan perlakuan konsentrasi ekstrak 30\% dan 40\%.. Penurunan terjadi seiring dengan bertambahnya konsentrasi ekstrak yang diberikan. Hal ini sejalan dengan penelitian Susilowati (2012) pemberian ekstrak daun kirinyuh mampu menurunkan bobot segar dan bobot kering akar dan tajuk gulma bayam duri. Menurut Alfandi dan Dukat (2007) bobot segar merupakan total kandungan air dan hasil fotosintesis di dalam tubuh tumbuhan, hambatan penyerapan air dan proses fotosintesis menyebabkan total kandungan air dan hasil fotosintesis berkurang pada tanaman. Hal tersebut akan mempengaruhi penurunan bobot kering.

Pengaruh alelokimia dalam menurunkan bobot segar dan bobot kering tanaman diduga karena alelokimia merusak permeabilitas membran plasma sehinggamenyebabkan kecepatan penyerapan ion tertentudan air mengalami penurunan dan berakibat pada penyempitan celah 
stomata, air berperan penting dalam proses fotosintesis, ketika terjadi penghambatan penyerapan air oleh tanaman maka proses fotosintesis tidak berjalan dengan optimal sehingga energi yang dihasilkan juga sedikit. Hal ini berakibat pada hasil fotosintat yang dihasilkan juga sedikit atau mengalami penurunan. Menurut Marina dan Ahadiyat (2016). Senyawa alelokimia golongan fenol dapat menghambat fungsi fisiologis di dalam jaringan yang menyebabkan terganggunya proses penyerapan nutrisi dan fotosintesis yang nantinya akan berpengaruh terhadap kecukupan nutrisi, sehingga pertumbuhan vegetatif tanaman akan terganggu karena sedikitnya nutrisi yang diserap kemudian menyebabkan berat basah akan berkurang dan menyebabkan fotosintat yang dihasilkan juga sedikit. Hal ini menyebabkan bobot kering yang dihasilkan menja direndah.

\section{KESIMPULAN}

Alelokimia ekstrak daun kirinyuh bersifat autoalelopati karena dapat menghambat pertumbuhan gulma kirinyuh. Semakin tinggi konsentrasi ekstrak dari $10 \%$ sampai $40 \%$ penghambatan semaikin kuat.

\section{DAFTAR PUSTAKA}

Alfandi dan Dukat. 2007. Respon Pertumbuhan dan Produksi Tiga Kultivar Kacang Hijau terhadap Kompetisi dengan Gulma pada Dua Jenis Tanah. Jurnal Agrijati 6 (1) : 26 29.

Anggriani, Kiki. Fatonah,Siti. Herman. 2013. Potensi Ekstrak Daun Chromolaena Odorata (L.) Dan Piper Betle (L.) Sebagai Herbisida Organik Terhadap Penghambatan Perkecambahan Dan Pertumbuhan Mikania Micrantha. Skripsi. Jurusan Biologi Fakultas Matematika dan Ilmu Pengetahuan Alam. Universitas Bina Widya Pekan Baru.

Campbell, N.A, J.B. Reece and L.G.Mitchell. 2010. Biologi. Alih Bahasa : L.Rahayu, E.I.M Adil, N Anita, Andri ,W.F Wibowo, W.Manalu Jakarta: Erlangga .
Darmanti S., Santosa, K. Dewi. and L. H. Nugroho. 2015. Allelopathic Effect of Cyperus rotundus $\mathrm{L}$. on seed Germination. Journal of Bioma 17 (2): 61-62.

Djazuli, M. 2011. Alelopati pada beberapa tanaman perkebunan dan teknik pengendalian serta prospek pemanfaatannya. Prospektif 10 (1): 44-50.

Frastika, D. Pitopang, R dan Suwastika, I, N. 2017. Uji Efektivitas Ekstrak Daun Kirinyuh (Chromolaena Odorata L.) R. M. King Dan H. Rob) Sebagai Herbisida Alami Terhadap Perkecambahan Biji Kacang Hijau (Vigna Radiata (L.) R.Wilczek) Dan Biji Karuilei (Mimosa Invisa Mart. ex Colla). Journal of Science and Technology 6 (3): $225-238$.

Hendry, G. A. F., dan J. P. Grime., 1993. Methods on comparative plant ecology, a laboratory manual. London : Chapman and Hill.

Haryanti, S dan Meirina, T. 2009. Optimalisasi Pembukaan Porus Stomata Daun Kedelai (Glycine max (L) merril) Pada Pagi Hari dan Sore. BIOMA 11 (1): 18-23.

Junaedi, A., Chozin, A.M., Kwanghokim. 2016. Current Research Status of Allelopathy. Jurnal Hayati 13(2): 79-84.

Li, Zhao, H. Wang, Q. Xiao, R. Cun, De Pa and Jiang D. 2010. Phenolics and Plant Allelopathy Review. Molecules15: $8933-$ 8952.

Marina, T dan Ahadiyat, Y. G. 2016. Respons Pertumbuhan Jagung (Zea Mays L.) terhadap Pemberian Ekstrak Gulma: Skala Laboratorium. Jurnal Agrin 20(1): 54-63.

Shannon F. S. \& Firestone J. 2015. Allelopathic potential of invasive species is determined by plant and soil community context. Plant Ecol. 216: 491-502.

Sharma, Pallavi. Jha, A,B. Dubey, R,S. 2012. Reactive Oxygen Species, Oxidative Damage and Antioxidative Defense Mechanismin In Plants under Stressful Conditions. Review Article. J. Bot. Vol 2012. Article ID 217037. doi: $10.1155 / 2012 / 217037$. 
Sindel, B., \& Coleman, M. 2010. Weed Detection and Control on Small Farms. Australia Government, Australia.

Song Ai, Nio. Sri, M. T. dan Regina, B. 2010. Evaluasi Indikator Toleransi Cekaman Kekeringan pada Fase Perkecambahan Padi (Oryza sativa L.) JurnalBiologi 14 (1): 5054.

Susilowati, erna. 2012. Perkecambahan dan Pertumbuhan Gulma Bayam Duri Pada Pemberian Ekstrak Kirinyuh (Chromolaena Odorata L.) . Skripsi. Jurusan Biologi FMIPA Universitas Sebelas Maret, Surakarta.

Thamrin M, S. Asikin, M. Willis. 2013. Tumbuhan Kirinyu Chromolaena Odorata (L) (Asteraceae: Asterales) Sebagai Insektisida Nabati Untuk Mengendalikan Ulat Grayak Spodoptera Litura. Jurnal Penelitian dan Pengembangan Pertanian 32(3): 112-121.

Yu J.Q., Ye S.F., Zhang M.F. \& Hu W.H. 2003. Effects of root exudates and aqueous root extracts of cucumber (Cucumis sativus) and allelochemicals, on photosynthesis and antioxidant enzymes in cucumber. Biochem. Syst. Ecol. 31: 129-139.

Yulifrianti, Elvrina, Riza linda, Irwan Lovadi. 2015. Potensi alelopati Ekstrak Serasah Daun Mangga (Mangifera indica L) Terhadap Pertumbuhan Gulma Rumput Grinting (Cynodon dactylon L) Press. Protobion 4 (1): 46-51.

Zhou Y.H. \& Yu J.Q. 2006. Allelochemicals and photosynthesis, pp. 127-139. In: Reigosa M.J., Pedrol N. \& González L. (eds), Allelopathy. Springer Netherlands. 